\title{
POSITIONING ISLAMIC LEGAL THEORY IN THE DEVELOPMENT OF ISLAMIC FINANCE
}

\author{
Nuha Qonita \\ Durheim University Business School \\ Email: nuhaqonita104@gmail.com
}

Abstract

Islamic finance continues to grow over the world, the development of technology plays a crucial role to support Islamic finance. The great innovation of technology may come to dig up the potential of Islamic financing, yet digital system needs for sharia compliance, both are in similar needs for sharia overviews regardless different opinions of ijtihad in this modern time. Emphasizing case by case of Islamic finance has been done by the sharia scholars in producing the new product of Islamic banking and financing. The Islamic jurisprudence however should consider the substence and maqasid form of sharia. The objective of this paper is to enlight some vital parts of Islamic legal theory as part of Islamic law in implementing sharia compliance. Furthermore, provide the role of legal system which takes a crucial place in implementing the system, it should be harmonized in the existing condition of Islamic finance. This paper is qualitative methods with deep analysis on Islamic legal theory among muslim scholars.

Keuangan syariah terus tumbuh di berbagai negara, perkembangan teknologi juga memainkan peran penting dalam mendukung keuangan syariah. Inovasi teknologi yang mutakhir dalam mendukung sistem keuangan syariah tentu membutubkan kepatuhan syariah yang sesuai di era modern ini. Penekanan kasus demi kasus keuangan syariah telah dilakukan oleh beberapa experts dalam menganalisa produk baru perbankan dan keuangan syariah. Namun, bagaimanapun yurisprudensi dalam sistem hukum syariah harus mempertimbangkan substansi dan bentuk maqasid dari syariah itu sendiri. Tujuan dari tulisan ini adalah untuk menerangi beberapa bagian penting dari teori hukum Islam sebagai bagian penting dari hukum Islam dalam menerapkan kepatuhan syariah atas pembiayaan syariah, terutama kebutuban terkini dari sistem transaksional melalui digital dan teknologi. Selanjutnya, tulisan ini juga menyampaikan pentingnya peranan sistem hukum yang mengambil tempat penting dalam menerapkan sistem kepatuhan syariah, yang mana perlu diselaraskan dalam 
kondisi keuangan syariah yang ada. Sistematika penulisan ini menggunakan metode kualitatif melalui analisis mendalam pada bagian penting dari teori hukum Islam dalam mengungkapkan sebuah hukum dikasus-kasus kontemporer.

Keywords: ijtibad, Islamic finance, 'illah, sharia compliance, and maqasid

\section{Introduction}

\section{Global Development of Islamic Finance}

Islamic finance is the fastest growing sector over the world not only for muslim country, it shows that UK as the largest country in Islamic Finance industry among Organisation for Economic Co-operation and Development Country (OECD). ${ }^{1}$ The new players also have initiated to develop Islamic finance such Australia which has continued support from the industry as well Uganda that publish interest-free rules banking. The principle of Islamic finance that is free from usury, gambling, transparency and risk sharing is an interesting and unique concept that applied in the financial transaction system worldwide. ${ }^{2}$

The development of Islamic finance is currently reported to reach 2,438 Bn by 2017, with the 10 largest countries are Iran, Saudi Arabia, Malaysia, UAE, Qatar, Kuwait, Bahrain, Indonesia, Turkey and Bangladesh. ${ }^{3}$ In term of increasing number of Islamic financial assets, the definition and purpose of Islamic finance remains a major point in boosting the potential of Islamic finance in the world. Fast changes and innovations motivate Islamic finance to adapt and become a modern system and structure but still consistent to comply Sharia and accordance with its objective.

Islamic finance continues to grow and innovate, such product combination and new contract has offered people expectation for an ethical financing. Better financing on Islamic finance increases people awareness around the concept and essence of Islamic finance and the objective of sharia. Nowadays, Islamic finance is internationally recognised instrument within different legal systems depends on the regulatory of country. The approaches of Islamic financial instrument also will be different for each country.

A pioneering experiment in implementing Islamic financial principle was conducted by Mit Ghamr from 1963 to 1967 to build Islamic banking as an

1 Reuters, T. State of the Global Islamic Economy Report, (2018/2019), p. 43

2 Mosabh I Tabash and Raj S Dhankar, "The Relevance of Islamic Finance Principles in Economic Growth", International Journal of Emerging Research in Management and Tecnology, Vol. 3, Issue 2 (February, 2014): 49-51.

3 Reuters, T. State of the Global Islamic Economy Report, (2018/2019), p.45 
alternative way to avoid riba on conventional bank. This implementation of Islamic banking is more than eliminating interest/riba but also educating people about the use of banking. After decades, financial transaction continued to innovate into several instruments toward digital system. The strong development of digitalization become an emerging trends that used by Islamic finance as a new tools. This may contribute significantly to attract people's expectation in defining Islamic financial product as well its substance. The transparency and good governance practices were the reason for investor confidence in controlling their investment.

Financial technology however has been adopted as a strategic tool that can encourage sharia compliant products that drive financial inclusion, as well as impact effectiveness, efficiency, transparency and ease of access to financial transactions. As new way of delivering core of Islamic finance transaction through financial technology, it must be proactive rather be reactive, it must be dynamic mechanism to trigger the innovation in the digital era. Sharia contract that tied in Islamic financial technology should not be restricted to the replication and fit on conventional financial contract, through digital financing the uniqueness of Islamic finance should be implemented and represent the essence of Islamic finance itself. ${ }^{4}$

The practice of transaction in fintech however should follow the contract that conducted, as well as pillars and conditions. In addition, it should achieve the objective of sharia. ${ }^{5}$ The compliance of sharia means relevant to laws, rules and regulations that accordance to basic rule of Islamic law. The permissibility in Islamic law provides a flexible room for Islamic financial transaction to innovate through digital system.

The concept of permissibility being the original ruling of sharia was constituted as vital tool for the sharia scholars to promote new product of transaction in Islamic banking and financing. Any new structured will be deemed as permissible as long as those products are free from prohibited elements. ${ }^{6}$ Addition to that, as well the development of digital economy has no sharia issue as long as the prohibitions are not included in the operational system of companies product, while sharia overview is needed in term of ownership in the area of capital and contract in new models of digital transaction. The new development of digital product also will need a smart contract that can fulfill the expectations of customer. Since, all the system depends on the code or form of computer there will need a comprehensive

4 Laldin, P. D., \& Djafri, D. Fintech in Islamic Finance and Its Shariah Parameter. Doba Islamic Finance Conference. (2019), p. 126.

5 Laldin, P. D., \& Djafri, D. Fintech in Islamic Finance and Its Shariah Parameter. Doba Islamic Finance Conference. (2019), p. 125.

6 Abozaid, A. Critical Review of the Tools of Ijtihād. Islamic Economic Studies, (2016), p.3 
legal info and any consequences regarding the contract, in order to disclose related benefits and penalties among parties.

\section{The Development of Islamic Finance in Indonesia}

Islamic finance in Indonesia has been existed over 2 decades since Bank Muamalat Indonesia is built as the first Islamic bank in Indonesia on 1992. The demand and interest on Islamic finance in Indonesia is getting greater and has supported Islamic finance industry in Indonesia to create various instruments and expecting a great response from consumer. ${ }^{8}$ Its development continues to forming a better infrastructure that support the development of Indonesian Islamic finance industry including Islamic banking industry, non-Islamic banking industries such as Islamic insurance, Islamic microfinance, Islamic capital market and social religious funds including zakat and waqf.

Together all of the stakeholders are involved to commit the development of Islamic finance. This commitment is implied into ruling structure of Islamic financial instrument, development of product, and also litigation system in Islamic financial transaction. In addition to that, as well other countries are improving the infrastructure of Islamic finance through Islamic finance standards, regulations and industry by expanding on ethical/social finance product and services. Consumers demand have rely on social impact and ethical financial services as well Investors to invest in high social impact fund with high to medium financial return. ${ }^{9}$

Within these days, the development has been expanded into digital financial transaction on financial technology, services, trades and intermediary platform between the real sectors and the investors. Despite its significant growth and the development, the overall size of the industry remain modest and so as its role to national economy. With the integration of Islamic financial system, there is unprecedented transaction intercourse among people of diverse background. Different issues and challenges in different sectors has been identified are; overlapped rules and regulations among players, capital insufficiency across Islamic commercial banks and Islamic rural banks, capacity issues within Islamic financial sectors in product features, competitive pricing, IT systems, service levels and distributions, limited supervision in microfinance and others.

7 Ahmed, D. H. Role of Digital Economy in Realization of Inclusive Growth. Islamic Finance and Digital World, (2019), p. 54. Doha. p.46

8 Muhammad Abduh and Azmi Umar,"Islamic Banking and Economic Growth: the Indonesia Experience", International Journal of Islamic and Middle Eastern Finance and Management, Vol. 5, (March, 2012): 35-47.

9 Reuters, T. State of the Global Islamic Economy Report, (2018/2019), p. 46. 
In line with those challenges of Islamic financial development, by 2019 the Supreme Court of Indonesia has dealt with 27 cases of Islamic finance in cassation level, it has increased by last year which was only 15 cases on cassation level. Different cases of Islamic finance occurred in various financial institutions and product development of Islamic finance. The sharia courts has dealt with the cases differently in the basis of Act No. 3 Series of 2006 on Islamic banking, which states, 'The implementation of the Sharia-compliant case, sharia and fiduciary rights based on Sharia contracts is done by the court within the sharia court'.

Arguing that, the legal of Islamic finance has been a crucial issue to be addressed. The potential of Indonesia in developing Islamic economics and finance should be supported. The standard and regulation of Islamic finance should be not overlapped each other to enhance the validation, efficiency, effectiveness and compliancy of Islamic financial product. Furthermore, the innovation and development of financial system grew rapidly over the years, to be more precise, the feature of Islamic finance need to be addressed properly. The innovation and development however, need a sufficient legal protection to sustain its development.

The dynamism of life has given rise to many system of innovations and developments including the financial system. People needs for a transparent, fair, effective and efficient financial system as well needs sharia compliancy on their transactional system. In these very latest modern innovation, it is worth to mention that the first basis legal theory in Islam as the origin of God's creation of things is permissible. It is not haram except that there is a correct text from that forbids it. If the text is not valid as some of the weak hadeeths, or if it is not explicitly stated in the hadeeth of haram, it is still valid on the basis of permissibility. Shaykh alIslam Ibn Taymiyyah said that the acts of worshipers are words and expressions of sorts of acts of worship that fit their religion and habits which they need in their world. In the fundamentals of the Sharia, we know that the acts of worship that Allah has enjoined and loved. ${ }^{10}$

The rules that implied in shariah is the main foundation to reveal any cases that occurred in modern time. Nevertheless, it is crucial to note Islamic jurisprudence is not only concerned with the enforcement of prohibition on riba, gharar and maysir but also on how financing and transactional system is structured and well used. Financing is a tool to facilitate productivity transaction for goods and services among social transaction and was not an end to merely making money from money for no purpose. ${ }^{11}$ Social transactions such as sales, grants, renting and so on are the

10 Qardhawi, D. Y. الحلال و الحرام في الاسلام. (Cairo: 1997 (مكتبة و هبة (2.) 17.

11 Wilson, R. Legal, Regulatory and Governance Issues in Islamic Finance . (Edinburgh: Edinburgh University Press, 2012), p. 2. 
humans need in socio life, as well as clothing, food and shelter needs. Sharia has been present in these customs in the form of ethical and good guarding from any damages, requiring what must be done, prohibiting what should not to do and allowing any matters on behalf social welfare and human wellbeing.

\section{Research Method}

\section{Ijtihad and Islamic Economy}

Islamic law is the end of the laws that carry the divine guidance of mankind. Allah has singled them out in general and eternity and inclusiveness. It is the mercy of Allah to the universe of all races and all the typhoons in all fields of life, where the provisions which makes them able to meet human renewal over time and evolution of mankind. But this law was also what Allah has created for factors of capacity and flexibility, and what the scholars had to diligence in which there is no definitive evidence of the provisions (الدليل القطعي) there is no text or evidence, and there is a thought evidence (الدليل الظني) as the field of Ijtihad.

Ijtihad is the one way gives Sharia fertility, which also enables the guidance of lifetime that Allah loves and satisfies by without violating Allah's rules and boundaries, nor denying the human rights. Therefore the correct ijtihad should fulfil its condition and provisions. ${ }^{12}$ Making it easier to obtain a legitimate ruling has been done in the manner of deduction, there are term and condition for Mujtahid to obtain the rules, 1) knowledge of Quran; 2) Knowledge of Sunnah ; 3) Knowledge of Arabic; 4) Knowledge of consensus positions; 5) Knowledge of Ushul Fiqh ; 6) Knowledge of the Objective of Shariah; 7). Knowledge of people and life; 8) Justice and piety. ${ }^{13}$

Nevertheless, there were different overviews in questioning does Ijtihad door is closed. Iqbal Lahori considered that close gate of $i j t i h a d$ to be a pure fiction, then he said that 'if some of the later doctors have upheld this fiction, modern Islam is not bound by this voluntary surrender of intellectual independence'. Following that Abu Zahrah has also criticized by said 'How could anyone be right in closing the door that God Almighty has opened for the exertion of the human intellect?'. The other view was said that 'ijtihad by individuals in the manner that was practiced by the fuqaha of the past is no longer fit for modern conditions. ${ }^{14}$

12 Yasmin Hanani Mohd Safian, "Shariah Scholars and Fatwa Making Process in Islamic Finance", Journal of Fatwa and Management Research, Vol. 10, No. 1 (December, 2017): 130-132.

13 Qardhawi, D. Y. الاجتهاد في الشريعة الاسلامية, (Kuwait : (1ار القلم, 1996). p.15.

14 Kamali, M. H. Principles of Islamic Jurisprudence, (1991), p.176. 
The main question will be 'does ijtihad is still needed and compulsory in this modern era?'. Some will argue that the ontology resources and the classical resources are complete and no need to do ijtihad in the modern era. It may be true as some scholar will directly refer to the some cases that occurred in the past and have been discussed with madzhabs. As well as that deriving the new fatwa of modern cases should refer to the resources, text and measurement. It has been asked, does ijtihad is allowed in this era. Some scholars argued doing Ijtihad after the period of Mujtahid is prohibited due replacing and repositioning Rasulullah as his role of the Massanger to send Allah's message for what allowed and what is banned.

Imam Shaukani implied that is not hidden ijtihad is obligatory regardless in the period of Mujtahid, as Rasulullah said "There will always be groups from my people who will defend the truth until the Day of Judgment comes" 15 . However, every age has its problems, its reality, its renewed need, and the earth is spinning, the waves are moving and the science is moving, with this continuing condition and period, there are modern causes that have not happened in the past and no any scholars have experienced the similar cases and issues. This is what made them decide that fatwa should be changed with the change of time, place, custom and situation. ${ }^{16}$

In this regard, Islamic economy and Islamic financial transaction is dynamic, the cases and experiences may be similar with the cases that happened in the past, while other may be a complex issue that happened in the past and another part is a new case, the world may face very modern and complicated experience that may occurred in past in the different or similar way of what is happening in time. It is important to highlight after all mentioning that sharia compatible financial contract is conducted by positioning suitable contracts from classical literature and adapting in modern cases of financial practices. Any cases that have not been occurred in the past should be revealed and identified based on ijtihad of the scholar to take place.

Existing model of Islamic financial products and services are developed in different approached; firstly, identifying existing conventional products and services and framing into Islamic product by removing prohibited elements on it; secondly, by involving sharia principles to develop the fully fledge innovation of Islamic financial products and services. It is said, Islamic finance is all about law and can only be understood by identify to its principle of jurisprudence and

وعن عمر بن الخطاب رضي اله عنه قال : قال رسول الله صلى الله عليه وسلم : ( لا تزال طائفة من أمتي ظاهرين على 15

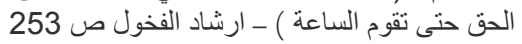

16 Qardhawi, D. Y. الاجتهاد في الشريعة الاسلادية (ارشاد . P, 63. 
rediscovery the substance of the contract in the classical ages of Islam and interprete it into modern case. ${ }^{17}$

Islamic jurisprudence takes a crucial role as a part of Islamic legal theory that offer great stability and sustainable values. The values in Islamic law is not always be validated on rationalist ground, as well human reason that always take an important role in the development of sharia through ijtihad, it is because Sharia is primary founded in divine revelation.

The Muslim jurist has faced the dynamic changing conditions of contemporary life that also has given different opinions. It is true the differences of overviews among Muslim scholars are inevitable in Islamic law. However, it is worth to mention that the differences opinion also occurred even in the period of Prophet Muhammad (PBUH), during the time of revelation and amongst the Companions before the Prophet decided on the differences and overviews.

The differences occurred, however, because Quran verses and the Prophetic traditions that may open for different interpretations. Some words in arabic can be defined in different ways and meaning. In this regard, Ibn Rusyd on his book Bidayat al Mujtahid wa Nihayah al-Muqtasid, was analyzed that differences of opinion in one cases of requirement of guardianship in a marriages contract, and he concludes by saying that cause of difference overviews is because there is no verse of Quran and the Traditions of Prophet that clearly stated guardianship as a condition for the marriage contract. ${ }^{18}$

Regardless those vary overviews, however, such theory in rationalizing legal instrument is applied in process of ijtihad such istihsan, istislah, syad dzarai' (blocking the means). The process of rationalizing is allowing the jurist to use their own discretion (ra'y) in determining a decision for legal issues. Although the jurists and scholars may designed different methods of ijtihad and results, in essence, they all are designed to promote the maqasid sharia (objectives of sharia). ${ }^{19}$

\section{Discussion}

\section{Proof of Sharia and Ratio Decidendi ('illah)}

17 Warde, I. Islamic Finance in the Global Econom, (Edinburgh: Edinburgh University Press, 2000) p.11.

18 Bakar, D. M. (2016). Shariah Minds in Islamic Finance.

19 Ercanbrack, J. G. The Transformation of Islamic Law in Global Financial Markets. (Cambridge: Cambridge University Press, 2015), p. 22. 
The proofs of Sharia as the main source is divisible into transmitted proofs (adillab naqliyyah) and rational proofs (adillah aqliyyah), the rational proofs is defined as a reason and need to be rationally justified, these are; Qiyas, istihsan, istislah and istiishab are basically rational doctrines in many ways dependent on the transmitted proofs. Qiyas for instance is a rational proof but take part in the transmitted proofs to the extent that qiyas in order to be valid should be founded on established rules of Quran, sunnah or ijma. The process of qiyas however contained of a certain method that need illab in common with original law. ${ }^{20}$

Illah or ratio decidendi (common known in English common law) is a main part of Islamic legal theory as similar theory in the English common law system. In juridicial usage, 'illah means the ratio of the law, its value and its purpose. It refers to a rationale of an injunction which similar with hikmah, as the purpose and the objective of the law. One of identification of 'illah is the cause of the prayer, that the month of Ramadan is the cause fasting, owning asset and wealth is the cause of zakat and others similar conclusion with regard the illah have been proved in the evidence of Quran and sunnah, even so are disputed by ulama. ${ }^{21}$

An illah must be a constant, evident and regular attribute. In this regard, Islamic legal theory has structured the way of finding illah or basis of the ruling named as masalik illah (distinguishing), this rule is used by the jurists for identifying the main illab under three phases: ${ }^{22}$

1. Takhrij al manath means identifying the probable illah.

2. Tanqih al manath means disqualify some of qualities classified in first process.

3. Tahqiq al manath means confirming that selected quality is the actual cause (illab) and applying this current ratio/selected cause to the other cases with same ratio.

In this phase, the question arise does process of ratio/looking for cause in the Quran gives the mujtahid the green light to enquire into the causes behind its rules or it is simply to describe a better understanding of text. Ulama have different opinion on this issue, some of them simply indicated that Quran is a clear text with no reason for causes unless the Lawgiver mentions the clear indications to the contrary text. While the majority of ulama has looked that hukm or law in Shariah has contained of certain objectives.

It is known that the objectives of shariah is the purposes of which the texts

20 Kamali, M. H. Principles of Islamic Jurisprudence, (1991), p.180. Tawfique al-Mubarak and Nor Mohammad Osmani, "Aplication of Maqasid Shari'ah and Maslahah in Islamic Banking Practices: an Analysis", Conference Paper (0ctober, 2010): 2-10.

21 Kamali, M. H. Principles of Islamic Jurisprudence, (1991), p.40.

22 Bakar, D. M. Shariah Minds in Islamic Finance, (2016). 
are intended for orders prohibitions and partial judgments are sought to achieve them for humanbeing. The cause of rule in sharia is a reason for judgement and does not a destinantion to it. For instance the dispensation for pray in a trip and combination of pray, as well dispensation for fasting in ramadhan is caused by its trip/travel as 'illah/causes.

\section{Role of Legal System}

Economic law is the study of laws relating to the economy in an interdisciplinary and multidimensional manner. Normally, economic law is in the frame of civil law and partly in public law to achieve prosperity in the life of the nation and state. ${ }^{23}$ Over period of time, strengthening the law and governance has become a crucial part in the development of international organizations. Building the legal system and its governance is proving to be a complex task. It has been assumed that law and governance reform is a technical and managerial matter has allowed for the export of laws and transplantation of legal and administrative structure. The disappointing result, however the commitment on how laws, regulations, stakeholders, and institution operate on the real condition, in their socio-political context. Every involved part needs sufficient understanding on how actual experiences of law and governance program can give a significant impact and promote the development. ${ }^{24}$

In general, law in developing countries historically has formed by 4 layers. The deepest consist of recognized customary rules, followed by the layer of religious rules recognized, then the legal rules of colonial state and the uppermost layer is continuing modern national law, after 10 years it is improved into fifth layer named international law. ${ }^{25}$ However, above all layers of law, the main constrain is the fact that such law is in practice not functioning as it should. If the law does not function as it should, it will arise such problem for the society and the regulator. Its uncertainty has hindered people to have security in their life, as well their sustainibility of livelihoods, protection of goods, land, houses and families. For the regulator, uncertain legal system and ineffectiveness of policy has hindered them for development and policy implementation. Failure of law can be a hindrance for achievement of development and its objective.

It indicates, the ineffectiveness of law is caused by juridical and non-juridical

23 Suadi, A. Penyelesaian Sengketa Ekonomi Syariah. (Jakarta: Prenadamedia Group, 2018), p.4. 24 Otto, J. M. Sharia and National Law in Musli Countries. (Leiden: Leiden University Press, 2008), p.2. 25 Irianto, S., Otto, J. M., Pompe, S., Bedner, A. W., Vel, J., Stoter, S., et al. Kajian Sosio-Legal . (tt: Pustaka Larasan, 2012), p. 176. 
reason. Its ineffectiveness and incomplete law has hindered the regulator and stakeholder to use which law should apply in a concrete situation. Moreover, it is also complicated in ascertaining how all rules that are available should be interpreted. Real legal certainty actually includes understanding juridical legal certainty, but in certain situations it should become: 1) clear, consistent and available legal rules (accessible) that issued by state; 2 ) the government agencies apply the rules and submissive and obidient to it; 3 ) in the principle the majority of citizens agree on content and therefore adjust their behavior towards these rules; 4) the judges are independent to apply legal rules consistently for dispute resolution.

The main implication of this concise overview of laws and legal institutions is that policy making in this complex and dynamic field demands a constant comparative analysis of contested issues in key areas of national law and sharia. This analysis should be guided by recognition of the long-term trend towards the Rule of Law, which can be deducted from changing interpretations of sharia, from procedural and substantive national law shaped and effectuated by legal institutions, from the common dominance of the state over religious scholars, and from practices of non-enforcement. Such a trend could occasionally be supported by legal development co-operation, promoting the Rule of Law, including human rights, while considering the particular context of each Muslim country.

Policy Implications Policy analysis of conflicts in Muslim countries between sharia-based law and national and international Rule of Law standards should concentrate on: ${ }^{26}$

1. Major overall trends in legislation, administration and adjudication of shariarelated issues, both in particular countries as well as in comparative perspective;

2. Concrete-actual and legal-violations of Rule of Law standards, notably of human rights;

3. Verification of whether claims that a particular violation is actually based on Islam or sharia can be substantiated;

4. Checking how sharia-based administration of justice relates to prevailing customary law;

5. The general state of the legal system and its potential for improvement, especially from the perspective of justice-seekers

All indicate the legal practices and religious rules/ Islamic law in term of muamalat take an important place in economic development, as well Islamic economy and finance system. Trace back to Indonesia, the historians argue that Islamic religion entered Indonesia at the beginning of the early Islamic era. It 26 Otto, J. M. Sharia and National Law in Musli Countries, p.30. 
can be estimated that at that time existing muslim were familiar with Islamic law even though in the initial stage. After years the sultanate or the Islamic empire is arisen which named Kerajaan Islam Samudra Pasai on the east coast of Sumatra and expands to the north coast of the island of Java.

Ibn Batutah, a shepherd from Morocco said in his book that the inhabitants of the islands he visited were mostly syafii mazhab. in the Dutch colonial era several kinds of instructors from the general governor were found to be addressed to the regents, specifically on the north coast of Java to provide opportunities for muslim scholars 'ulama' to resolve civil disputes among the population according to Islamic teachings.

This even said that the decision of the Dutch king (Koninkelijk Besluit) No. 19 January 24, 1882 which was later announced in the Staatsblad in 1882 No. 152 regarding the establishment of a religious court (Pristerraad) based on the theory of Van Den Berg who adheres to the concept of receptio in complexu, which means that the law that applies to the indigenous is the religious law which he embraces. This can be influenced by the fact that Muslim natives are very obedient to sharia. However, Van Den Berg's theory was opposed by Snouck Hurgronje, who adhered to the concept of 'receptie' theory which in essence stated that Islamic law was seen as law if it was maximized by customary law. In Its journey, however, it is inevitable Islamic law is applied in Indonesia, such as marriage law, inheritance, shared assets. According to the doctrine, the law will only enforced if it is supported by three supporting pillars are 1) a reliable legal apparatus 2) clear legal regulations 3) high public awareness. ${ }^{27}$

Law and finance stand as body that has dominated policy-making. Law and finance play as identity in observing alternative strategies for analyzing the law and legal institution with the involvement for both legal and economic change. In rationalizing the theory between financial development and legal determinant has been discussed in different overviews. There are different indicators to examine the relationship between financial intermediary development and measures of national legal and regulatory conditions; first, financial intermediary development; second, legal and regulatory characteristic for cross countries.

The increase disputes of Islamic finance in the supreme court has showed uncertainty of regulation and standard in Islamic financial product, this matches between theory and practices should be addressed, in a way the objectives of sharia is the foundation. Legal risk and sharia risk arise in questioning Islamic financial

27 Ahmad, A., Munji, S., Djazuli, M., Kamil, A., \& Hakiem , L. Dimensi Hukum Islam dalam Sistem Hukum

Nasional, (Depok : Gema Insani, 1996), p.55. 
product in term of compliancy.

Emerging the law of Islamic finance in Indonesia has become a major role to support the development and sustainable of Islamic economy and finance in Indonesia. Supporting infrastructure of legal standing is a great opportunity for digging the potential of Islamic economy and finance in Indonesia through various ways. Through an effective legal standing, the stakeholders and institutions have structured derivatives rules and regulation for the industry of Islamic economy and finance.

Indonesia has applied an unique legal system as civil law, intermixed with Islamic law system and customary law. It is an opportunity to create an effective, efficient and comprehensive ruling structure for development of Islamic economy and finance, which is expected to contribute significant impact for economic development. Nevertheless, it needs compatible structure between transforming Islamic law into modern practices of financial market throughout its method, and applied in current Indonesia legal system.

\section{Conclusion}

The development of financial transaction continuous to increase, needs of sharia compliance on financial transaction is also growing. The innovation and improvement system is inevitable, Islamic economy and finance, however, should have sustain and following the global transformation. As innovation is getting greater, sharia compliant product is a major needs for all industries and stakeholders. Sharia scholars have identified modern cases by their process of ijtihad as well their phases of legal theory in Islamic law and describe it to the public. Yet, law enforcement as legal standing of sharia compliance is also important due certainty of Islamic financial system itself. As starting stage, however, to implement basis system of sharia compliance, providing an effective guidline that contained of basis or foundation of sharia compliance on financial services and products or other transactional system is highly crucial. Such modern and accessable tool to provide people needs of sharia compliance and its principles would concretely be benefecial.

\section{Bibliography}

Book

Abozaid, A. Critical Review of the Tools of Ijtihād. Islamic Economic Studies. (2016). 
Ahmad, A., Munji, S., Djazuli, M., Kamil, A., \& Hakiem , L. Dimensi Hukum Islam dalam Sistem Hukum Nasional. Depok : Gema Insani, 1996

Ahmed, D. H. Role of Digital Economy in Realization of Inclusive Growth. Islamic Finance and Digital World, (2019)

Bakar, D. M. Shariah Minds in Islamic Finance. (2016)

Chapra, M. U. The Future of Economics; an Islamic Perspective. Leicester: The Islamic Foundation. 2000.

Ercanbrack, J. G. The Transformation of Islamic Law in Global Financial Markets. Cambridge: Cambridge University Press. 2015.

Irianto, S., Otto, J. M., Pompe, S., Bedner, A. W., Vel, J., Stoter , S., et al. Kajian Sosio-Legal. Pustaka Larasan, 2012.

Kamali, M. H. Principles of Islamic Jurisprudence. (1991).

Laldin, P. D., \& Djafri, D. Fintech in Islamic Finance and Its Shariah Parameter. Doha Islamic Finance Conference. (2019).

Otto, J. M. Sharia and National Law in Musli Countries. Leiden: Leiden University Press. 2008.

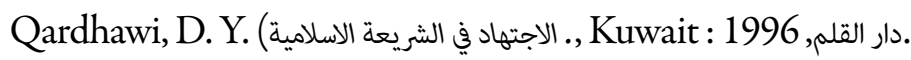

Qardhawi, D. Y. الحلال و الحرام في الاسلام., Cairo: مكتبة وهبة, 1997.

Qardhawy, D. Y. مدخل لدراسة الشريعة الاسلامية), Beirut: مؤسسة الرسالة, 1993.

Reuters, T. State of the Global Islamic Economy Report, (2018/2019).

Suadi, A. Penyelesaian Sengketa Ekonomi Syariah. Jakarta: Prenadamedia Group, 2018.

Warde, I. Islamic Finance in the Global Economy, Edinburgh: Edinburgh University Press, 2000.

Wilson, R. Legal, Regulatory and Governance Issues in Islamic Finance, Edinburgh: Edinburgh University Press. 2012.

\section{Article}

Muhammad Abduh and Azmi Umar," Islamic Banking and Economic Growth: the 
Indonesia Experience", International Journal of Islamic and Middle Eastern Finance and Management, Vol. 5, (March, 2012): 35-47.

Mosabh I Tabash and Raj S Dhankar, "The Relevance of Islamic Finance Principles in Economic Growth", International Journal of Emerging Research in Management and Tecnology, Vol. 3, Issue 2 (February, 2014): 49-51.

Yasmin Hanani Mohd Safian, "Shariah Scholars and Fatwa Making Process in Islamic Finance", Journal of Fatwa and Management Research, Vol. 10, No. 1 (December, 2017): 130-132.

Tawfique al-Mubarak and Nor Mohammad Osmani, "Aplication of Maqasid Shari'ah and Maslahah in Islamic Banking Practices: an Analysis", Conference Paper (0ctober, 2010): 2-10. 